\title{
NATIVE OR NATURALIZED? VALIDATING ALPINE CHAMOIS HABITAT MODELS WITH ARCHAEOZOOLOGICAL DATA
}

\author{
Martin Baumann, ${ }^{1,4}$ Caroline Babotai, ${ }^{2}$ And Jörg Schibler ${ }^{3}$ \\ ${ }^{1}$ Wildtierbiologischer Arbeitskreis WildARK, Tillierstrasse 6a, CH-3005 Berne, Switzerland \\ ${ }^{2}$ Swiss Federal Institute of Forest, Snow and Landscape Research WSL, Zürcherstrasse 111, \\ CH-8903 Birmensdorf, Switzerland \\ ${ }^{3}$ Institute for Prehistory and Archaeological Science, University of Basel, Spalenring 145, CH-4056 Basel, Switzerland
}

\begin{abstract}
Conservation of mammal species often requires the application of predictive habitat models. While empirical models can indicate the potential suitability and distribution of recent habitat, they may fail to depict native habitat and distribution. Therefore, we advocate validating such models with archaeozoological data.

To demonstrate the power of archaeozoological data in investigating native distribution patterns, we use the alpine chamois (Rupicapra rupicapra) as a model species. After experiencing a severe historical population bottleneck due to overexploitation, chamois populations recovered markedly during the last century. Fostered by humans and having profited from translocations, this alpine ungulate greatly expanded its range and began to invade forested areas both within and outside the Alps, where damage to vegetation was soon obvious. Consequently, a controversy arose concerning the natural distribution and habitat of chamois. To study the native habitat and distribution of alpine chamois in Switzerland, we focus on the Late Mesolithic and Neolithic period (6000-2200 BC). This period best suits our purpose because pristine forests then dominated the landscape and human influence was as yet minimal. We describe two opposing habitat models: the alpine model assumes that chamois had survived only in alpine areas, whereas the forest model assumes that they also roamed in steep, entirely forested areas. We validate these models with archaeozoological data. Because the probability of chamois bone occurrence in prehistoric settlements is expected to decrease with increasing distance from chamois habitat, the models differ in their geographical predictions of chamois bone records. Applying logistic regression models, only settlement proximity to chamois forest habitat explains recoveries of fossil chamois bones. The resulting function of catchment distances (i.e., the likelihood of hunting chamois depending on the distance between a settlement and the nearest chamois habitat) matches the spatial behavior of extant hunters within pristine forests.

We conclude that Holocene chamois range in Switzerland naturally included steep and entirely forested regions, like the Jura Mountains. The recent invasion of these areas by chamois thus constitutes repatriation of native habitat. Accordingly, we propose a shift in perspective toward landscape integration of chamois.
\end{abstract}

Key words: archaeozoology; chamois; habitat modeling; Late Mesolithic; native distribution; Neolithic; restoration ecology; Rupicapra rupicapra; subsistence hunting; Switzerland; ungulates.

\section{INTRODUCTION}

Wild sheep and goat species (Caprinae) are conspicuous components of many mountainous ecosystems. Their range is often naturally fragmented, owing to the discontinuous distribution of crucial habitat features, such as steepness (Shackelton 1997). Additional fragmentation occurs through anthropogenic habitat loss (Pérez et al. 2002) or overharvesting (Purvey 2000). Therefore, any mismanagement readily leads to population declines. Small and disjunct populations are especially prone to extinction (Berger 1990), but the species may also become jeopardized by corresponding genetic erosion (Srikwan and Woodruff 2000). Today,

Manuscript received 4 June 2002; revised 20 June 2004; accepted 27 August 2004. Corresponding Editor: C. A. Wessman.

${ }^{4}$ E-mail: martin.baumann@wildark.ch more than $70 \%$ of wild Caprinae species are threatened and $30 \%$ are endangered (Shackelton 1997).

For the conservation of large mammal species, the ultimate goal must be to retain their evolutionary potential (Frankham et al. 2002). This goal may often be proximately achieved through conservation strategies that aim at maximizing the species' distribution within its native range (Maehr et al. 2001), while minimizing population fragmentation (Sherwin and Moritz 2000) and optimizing dispersal among subpopulations (Woodroffe 2003). Spatially explicit models are increasingly applied to predict species habitat (Guisan and Zimmermann 2000). Most models are empirically deduced, relating observed patterns of occupancy to environmental parameters (Corsi et al. 2000). Despite their wide application, such models also have drawbacks (Wiens 2002). One rarely considered point is that 
spatial models may fail to depict the native area of occupancy, not only due to changes in habitat availability, but also because past anthropogenic disturbance may have confounded the underlying patterns of habitat use. Hence, given an interest in the native status, extant patterns of habitat use and distribution should be viewed in the light of historical determinism (Patterson 1999), landscape change (Knick and Rotenberry 2000), and anthropogenic changes of faunal community structures (Berger et al. 2001).

Shrunken ranges are all too common today (Mace and Balmford 2000), but some species may have gained by invading new nonnative areas. The fitness of ungulates, for example, is known to vary with individual access to preferred habitat (Nilsen et al. 2004). Changes in spatial patterns of habitat conditions such as forage availability (Iason et al. 1986), predation risk (Skogland 1991), or cover (Mysterud and Ostbye 1999), may therefore be followed by changes in population density and distribution, as well as alterations in habitat use or landscape colonization (Pettorelli et al. 2001, Terborgh et al. 1999, Illius and Gordon 1997). Effects of this kind may themselves become conservation problems (Mack et al. 2000), as ungulate species can affect their habitat negatively, namely, by selective feeding and overgrazing of the vegetation (McShea et al. 1997). Hence, the central question becomes whether expansion constitutes invasion of nonnative habitat or repatriation of native but vacant habitat (Noss 2001).

The example of the alpine chamois (Rupicapra rupicapra) may illustrate this. In historic times (up until the middle of the 19th century), this valued prey of hunters was extirpated from most of Switzerland. The only remaining population fragments were in the Alps, and even the danger of total extinction seemed real (Baumann 1949). However, improvements in legal protection and wildlife management led to a successful recovery during the 20th century (Krämer 1995), and today's population estimate for Switzerland exceeds 100000 chamois (Giacometti 1997). Parallel to this population increase, and often initiated by translocations, chamois began to invade mountain ranges outside the Alps, namely, the Swiss Jura Mountains (Salzmann 1975), which consist primarily of forested habitat. Similar range expansions occurred in France (Corti 1995) and Germany (Schröder 1983). Outside their alpine core area, chamois were soon blamed for altering vegetation composition (Richard 1972) and impeding forest rejuvenation (Ammer 1996), typical phenomena of invasive herbivores (Rejmànek et al. 2002). Accordingly, conflicts of interest arose concerning conservation priorities. Assuming their nonnative status (Schröder 1985), it was recommended that forest habitat selection by chamois be discouraged by hunting (Scherzinger 1996). The eradication of certain forest populations of chamois was even proposed (Schröder and Elsner v. d. Marlsburg 1982), the reasoning being based on three facts: first, that most chamois popula- tions outside the Alps were established by translocations; second, that natural predators were missing during the establishment phase, because wolf (Canis lupus), lynx (Lynx lynx), and brown bear (Ursus arctos) were extirpated earlier (Woodroffe 2001); and third, that in historic times broad-scale forest fragmentation created numerous pastures within formerly closed forests that were considered necessary for chamois foraging (Herrero et al. 1996). These broad-scale habitat alterations were considered diagnostic for emerging chamois populations, because their "natural range" was thought to have been restricted to alpine areas (Schröder 1971), which, by then, only provided suitable foraging habitat that consisted of alpine grassland interspersed with rocky escape terrain (Schröder and Georgii 1988). The fact that the Pleistocene distribution of chamois included much of Central Europe outside the Alps (Couturier 1938) did not challenge this line of thought, because the emerging Holocene forest biome was entirely accredited with having displaced chamois from low-altitude ranges (Schröder 1983). Yet the question remains: Why do chamois presently tend to establish populations at low altitudes and in forests? Is this pattern of habitat selection only an artifact of human habitat alterations?

Ecological research alone cannot answer this question, because there are no study areas left that allow investigation of undisturbed habitat selection. Thus, a shift in time scale is necessary. We focus on a period when chamois ranging patterns were influenced by environmental factors similar to those of today, but before the influence of humans became predominant. The Late Mesolithic and Neolithic period (6000 to 2200 BC, i.e., calibrated radiocarbon years BC) qualifies as most appropriate: climatic conditions were then comparable to present-day conditions; vegetation was then largely the same as today's potential vegetation; pristine forests dominated the landscape; and human population density was very low with its environmental impact still negligible (Le Tensorer and Niffeler 1993, Stöckli et al. 1995).

To find evidence of native chamois distribution within this pristine forest landscape, we tested two habitat models: (1) the alpine model hypothesizes that chamois survived only in alpine habitat, i.e., above and around the alpine timberline; (2) alternatively, the forest model hypothesizes that in addition to alpine habitat, chamois inhabited forested habitat, i.e., the steep forests and low altitude mountain ranges outside the Alps.

We validated these opposing models with independent archaeozoological data, i.e., bones discarded by humans in their settlements' dump sites. We assume that the catchment probability, i.e., the likelihood of killing a prey and retrieving it, increases with the prey's increased proximity to a settlement (Broseth and Pedersen 2000). Thus, we expect chamois bone occurrence to vary with the settlement's distance to chamois range. 
Therefore, the two habitat models differ in their spatial predictions of fossil chamois bone records.

We apply logistic regression models and discuss our results with respect to the forage economy of Stone Age human hunters. Our approach will be of relevance not only for restoration ecologists and wildlife managers, but also for biogeographers and archaeologists, and we describe some possible applications.

\section{STUdy AREA}

Our study area consists of Switzerland $\left(46^{\circ} 45^{\prime} \mathrm{N}\right.$, $8^{\circ} 30^{\prime} \mathrm{E}$ ), including the shores of its border lakes and the small principality of Liechtenstein. With an approximate area of $41450 \mathrm{~km}^{2}$, Switzerland can broadly be divided into three geomorphologically and biogeographically distinct regions: the Alps $\left(27100 \mathrm{~km}^{2}\right)$, the relatively flat Central Plateau $\left(9400 \mathrm{~km}^{2}\right)$, and the Jura Mountains (4950 km²) (Gutersohn 1975). While the lowest parts of Switzerland are at $260 \mathrm{~m}$ above sea level (m a.s.1.), the Jura Mountains reach an altitude of almost $1700 \mathrm{~m}$ a.s.l., and the highest Alpine peaks exceed $4600 \mathrm{~m}$ a.s.l. Forest cover is $30 \%$ in the Alps, $26 \%$ on the Central Plateau, and $41 \%$ in the Jura Mountains. Fifty-three percent of Swiss forest area lies above $1000 \mathrm{~m}$ a.s.l. (Brassel and Brändli 1999). The potential alpine timberline lies between $1800 \mathrm{~m}$ a.s.l. (at the borders of the Alpine range) and $2400 \mathrm{~m}$ a.s.l. (in the central parts of the Alpine range) (Lang 1993).

\section{Study Period}

Consistent with the aims of our study, we tried to focus on a time period when habitat selection and distribution of alpine chamois were shaped by natural factors identical to those playing similar roles today, but when such selection and distribution were still mainly unaltered by humans. The study period should also allow us to reconstruct the wild ungulate community from archaeozoological records. This entails an optimization process involving three factors: environmental similarity, human impact, and archaeological constraints. In order to depict the best-suited period, we discuss the relevant topics in the following paragraphs.

Natural environment.-Today, Switzerland would naturally be covered by continuous zonal forests, with Norway spruce (Picea abies), beech (Fagus sylvatica), silver fir (Abies alba), and larch (Larix decidua) as the dominant species (Ellenberg 1988). From 60\% to 80\% of actual Swiss forests still have such a seminatural composition (Brassel and Brändli 1999), but the composition of Holocene forests has changed over time (Burga and Perret 1998). It was not until the Late Atlantic and Early Subboreal periods (i.e., between 4900 and $2500 \mathrm{BC}$ ) that all of the relevant tree species in present-day forests had entirely invaded Switzerland. These pristine forests formed a contiguous layer (Zoller and Haas 1995) and, depending on summer temperatures, even reached altitudes higher than today's potential timberline (Lang 1993). Within forests, the sta- ple diet of ungulates consists of plants in the herbaceous layer. Given the similarity of tree composition then and now, and considering natural forest structure, we assume that Late Atlantic and Early Subboreal forests offered, in the herbaceous layer, suitable forage plants for chamois, and that the amounts so offered were comparable to those offered by present-day forests (Burga and Perret 1998). Fossil records prove that the landscape then harbored wolves, lynx, and brown bears as the natural predators of chamois, which may have influenced their ranging patterns (Stöckli et al. 1995). Thus, with regard to natural environment, the Late Atlantic and the Early Subboreal periods suit our purpose well. Nevertheless, we must also consider human influence.

Human environmental impact.-The present-day Swiss landscape is entirely under the influence of human development, with Swiss forests fragmented and reduced to only $41 \%$ of their natural area (Brassel and Brändli 1999) and the alpine timberline lowered by 100-400 m from its natural level (Burga and Perret 1998). These habitat alterations occurred primarily during historic times. However, some low-intensity pulses of human impact can be traced to prehistoric times (Amman 1988). But it was not until the emergence of agriculture, i.e., the Neolithic transition, that such impacts became lasting (Stöckli et al. 1995). In Switzerland, agriculture was first adopted around 6000 BC (Erny-Rodmann et al. 1997), but the Mesolithic and Neolithic ways of life must have coexisted for a considerable time (le Tensorer and Niffeler 1993, Stöckli et al. 1995). Neolithic people cleared forests to create arable land, but not grassland pastures. Livestock feeding (cattle, goats, and sheep) depended entirely on forest vegetation (Stöckli et al. 1995). Human impact on the pristine vegetation can only be inferred for the immediate surroundings of settlements, which were concentrated in the Swiss Plateau region (Stöckli et al. 1995). Thus, major parts of the pristine Neolithic forests remained unaltered by humans (Zoller and Haas 1995, Schibler and Jacomet 1999). Likewise, no broadscale lowering of the alpine timberline can be inferred (Burga and Perret 1998). Depending on the size of the human population and its technological sophistication, environmental impact increased notably only after 3000 BC (Burga and Perret 1998, Schibler and Jacomet 1999). With the beginning of the Bronze Age (2200 BC), environmental impact was evident on a broad scale, and grassland pastures increasingly emerged (Müller et al. 1999). Therefore, in terms of human impact, the Late Mesolithic/Neolithic period suits our purpose better than later periods.

Archaeological perspective.-One basic assumption of our approach is that the fossil record mirrors the live assemblage of wild ungulate species in the settlements' surroundings. But because humans discarded bones, their deposition depended on human habits and decisions at various stages, from prey selection to lar- 
der processing (Metcalf and Balow 1992, Reitz and Wing 1999). Hence, on-site occurrence of species cannot be automatically inferred from either bone presence or absence. Still, certain circumstances enhance the likelihood of a species appearing in the fossil record. Human forage economy (i.e., the dependency of humans on calories from hunting) and archaeological complex size seem to be important determinants. The dependency of pre-Neolithic hunter-gatherers on hunting and foraging obviously lessened after the invention of farming (Le Tensorer and Niffeler 1993), a circumstance that disfavors the Neolithic and later periods. Yet, to a considerable degree, Neolithic humans in Switzerland still supplemented their subsistence farming with foraging, especially during periods of economic crash, i.e., during cooler climatic phases with regional cereal crop failures (e.g., Piora I and II) (Schibler et al. 1997, Maise 1998). However, from the Bronze Age onward, agriculture began to provide a secure basis for the human diet, and the importance of foraging gradually disappeared (Hochuli et al. 1998).

If a species was not selected as prey, its fossil record will be missing. Were chamois such avoided prey? Given the limitations of agricultural forage economy during the Neolithic period, Neolithic hunters likely tried to maximize their catch of highly nutritious prey (Kaplan and Hill 1992, Hawkes et al. 1997), which means that large-bodied animals most likely were the preferred prey (Bodmer 1995). For the Late Mesolithic and Neolithic period, we infer such selection patterns from the predominance of red deer bones (Cervus elaphus) in the fossil record. Red deer, with an eviscerated adult body mass of 60-120 kg (Niethammer and Krapp 1986), appear in $94 \%$ of the complexes and their bones contribute, on the average, $56 \%$ to the partition of bones from game animals; chamois, with a body mass of only 20-30 kg (Niethammer and Krapp 1986), appear in $22 \%$ of the complexes and, on the average, only $0.7 \%$ of all bones from game animals belong to this species. Yet this difference is not likely the consequence of avoidance of chamois as prey. If so, the even smaller roe deer (Capreolus capreolus), with a mean eviscerated body mass of 14-17 kg (Niethammer and Krapp 1986), should also have been avoided. But roe appear more frequently than chamois, i.e., in $79 \%$ of our complexes, and they contribute, on the average, $8 \%$ to the partition of bones from game animals. We explain this difference with the fact that roe, contrary to chamois, were ubiquitously distributed in Neolithic forests (Hufthammer and Sørensen 1998). We therefore conclude that Neolithic people hunted chamois as soon as they were available as prey.

A second basic assumption is that the neighboring habitats of settlements are mirrored in their fossil records. Here, human accessibility to the environment seems to be one of the most crucial determinants, walking being the most restricted transport system (Wilkie et al. 2000). Consequently, the catchment radius cor- responds to a few hours' walking distance from the settlements (Higgs and Vita-Finzi 1972). The criterion of walking was met up to the Neolithic period. The first evidence of domesticated horses and the use of cattle as draft animals appears only toward the end of the Neolithic period (Stöckli et al. 1995). Recovery of Neolithic dugouts indicates the potential for water transport (Stöckli et al. 1995), and this may compromise our results, because dugouts enlarged the catchment distance for inhabitants of lakeshore settlements. However, since such recoveries are rare, we infer a more restricted catchment radius for the Neolithic than for any later period.

Animal remains can also appear in the fossil record due to trade. Long-distance trade for valuable technological materials (e.g., flint or stone axes) was already established in the Neolithic period, but the same cannot be inferred for perishable goods (Stöckli et al. 1995, le Tensorer and Niffeler 1993). Hence, trade of forage goods is an unlikely cause for the systematic occurrence of chamois bones in Neolithic settlements.

Time period.- The Neolithic period (5500-2200 BC) best suits our study because it optimizes for environmental similarity, lack of human impact, and archaeological suitability. We include additional data from the Late Mesolithic period (6000-5000 BC), because the Neolithic transition (starting around 6000 BC) is considered a gradual process (Erny-Rodmann et al. 1997), with a considerable overlap of both periods (Le Tensorer and Niffeler 1993). Our period of comparison thus stretches from 6000 to $2200 \mathrm{BC}$, a time frame that we refer to throughout this paper as the "Late Mesolithic and Neolithic period."

Chronology of the Neolithic period in Switzerland is based on calibrated ${ }^{14} \mathrm{C}$ data and dendrochronology for the time between 3900 and 2400 BC (Osterwalder and Schwarz 1986, Stöckli et al. 1995). However, only uncalibrated ${ }^{14} \mathrm{C}$ data is available for most Late $\mathrm{Me}$ solithic finds. To simplify matters, we transform Late Mesolithic data to years BC, in accordance with suggestions from the literature (Osterwalder and Schwarz 1986).

\section{Archaeozoological Data}

We extracted archaeozoological data from publications up to 2001. Finds were aligned to the time envelope according to their physical dating (e.g., using dendrochronology or the ${ }^{14} \mathrm{C}$ radiocarbon method) or their typological description as cultural artifacts (e.g., Neolithic pottery fragments or Late Mesolithic trapezoidal flint tools; Osterwalder and Schwarz 1986, Le Tensorer and Niffeler 1993).

As a rule, the bones of domestic animals outnumber those of game in Neolithic complexes, and the latter are sometimes completely lacking (Stöckli et al. 1993). We omitted such purely domestic complexes, because these people may have subsisted on farming alone. Our sample consists of 154 archaeological complexes: sev- 


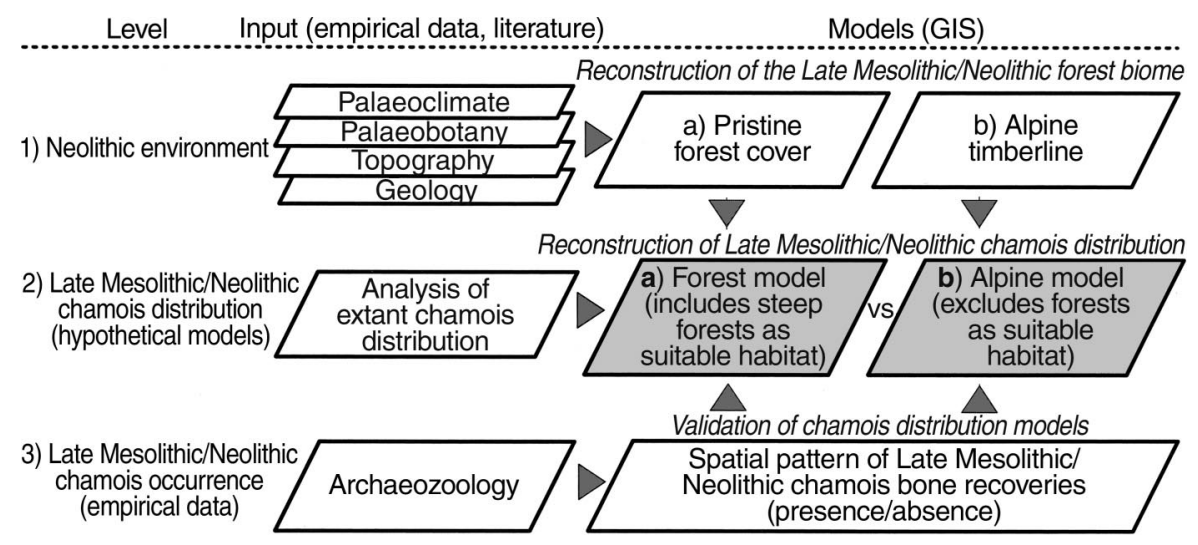

FIG. 1. Simplified conceptual model of the methodological steps applied to reconstruct Late Mesolithic/Neolithic chamois distribution. Two opposing distribution models result, a forest model and an alpine model, both of which are validated with empirical archaeozoological data.

en Late Mesolithic, and 147 Neolithic. These complexes may lie very close together, or even overlap stratigraphically, and the estimates of their occurrence in time may also overlap. In order to avoid pseudoreplication (Hurlbert 1984), we pooled complexes closer than $2 \mathrm{~km}$ from one another into one data point, thus providing a final sample of 47 find localities: five Late Mesolithic, and 42 Neolithic, each consisting of from one to 40 complexes. Additionally, we assume that increasing the local complex size partly eliminates the contingencies of small sample sizes, thus improving our estimates of local faunal community composition.

\section{Neolithic Chamois Distribution Models}

For Neolithic chamois, we constructed two opposing habitat models that differ in their predictions of chamois landscape distribution. We validated these models with archaeozoological data. The methodological steps are summarized in Fig. 1.

The alpine model regards continuous forests as unsuitable habitat for chamois, and assumes that Neolithic chamois were restricted to regions above and around the alpine timberline. The low-altitude border of chamois habitat may therefore be approximated by the alpine timberline itself, which we modeled by applying a zonal forest distribution model. This model works on a grid basis of $1 \mathrm{~km}^{2}$ and uses temperature as a driving variable, while also including basic geographical site factors, such as region, aspect, and bedrock (Brzeziecki et al. 1995). We transformed the resulting alpine timberline into a polygon. Literature on the paleoclimate states that mean summer temperatures during the Neolithic were, on the average, $1.0^{\circ} \mathrm{C}$ higher than today's temperatures, with estimates ranging from +0.6 to $+2.0^{\circ} \mathrm{C}$ (review in Huntley et al. 2002). Accordingly, the altitude of the alpine timberline was then 50-150 $\mathrm{m}$ higher than today's potential timberline, a fact confirmed by many paleobotanical studies (Burga and Perret 1998, Huntley et al. 2002). Yet, during phases of cooler climate (e.g., Piora I and II), the alpine timber- line was depressed to $50 \mathrm{~m}$ below today's potential timberline (Haas et al. 1998, Lang 1993). To include any effects due to such variation, we let the Neolithic summer temperatures vary between $-0.5^{\circ} \mathrm{C}$ and $+1.5^{\circ} \mathrm{C}$ as compared to today's temperatures, in steps of $0.5^{\circ} \mathrm{C}$. The resulting Neolithic timberlines vary approximately between today's summer isothermal lines of $8.0^{\circ} \mathrm{C}$ and $10.0^{\circ} \mathrm{C}$, corresponding to a variation in altitude of $300 \mathrm{~m}$. Fig. 2 presents Neolithic forest cover and chamois habitat according to this alpine model.

In contrast, the forest model assumes that Neolithic chamois were not restricted to alpine habitat but also inhabited steep forested areas within and outside the Alps. We inferred this type of habitat selection while analyzing extant chamois landscape distribution. We applied the following three methodological steps:

1. Empirical analysis of chamois habitat selection.-We conducted a total survey of chamois distribution for the Swiss canton of Bern in 1996. This canton varies in altitude from $400 \mathrm{~m}$ a.s.1. to almost 4300 $\mathrm{m}$ a.s.l., covers an area of approximately $6000 \mathrm{~km}^{2}$, and is partitioned into the three major biogeographical regions previously mentioned (i.e., the Alps, the Central Plateau, and the Jura Mountains). The survey was based on the expert knowledge of 33 professional game wardens, and we restricted it to female chamois to avoid interference due to sexually related differences in habitat use (Shank 1985, Loison et al. 1999). We mapped the areas of chamois occupancy as presence polygons (scale 1:50000), and transformed them into grid data (cell size $1 \mathrm{~km}^{2}$, threshold value 0.2 ). Only cells situated entirely within the canton's territory $\left(5533 \mathrm{~km}^{2}\right)$ were considered. The resulting binary variable (chamois presence/absence) became the dependent variable. We then used the Swiss Federal GIS databases to calculate the following set of independent environmental variables: altitude, slope, exposition, relief, glacier, forest cover, and forest area (Table 1). Independent variables displaying the proportion of area 


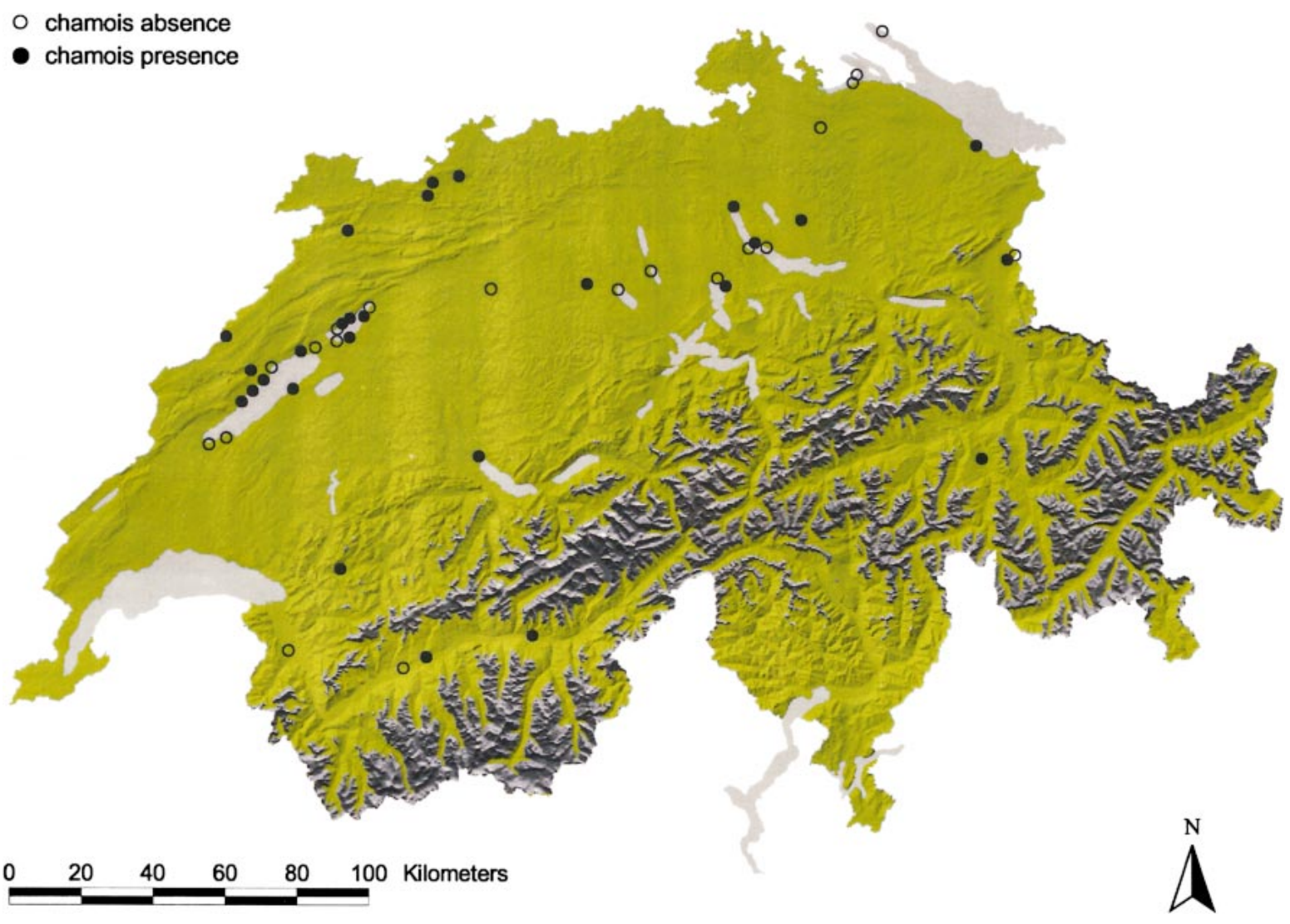

FIG. 2. Distribution model of zonal forests in Late Mesolithic/Neolithic Switzerland and chamois habitat according to the alpine model. Most of the landscape was covered with forests (green), except for lakes (light gray) and alpine regions (dark gray). The alpine timberline was elevated approximately $150 \mathrm{~m}$ as compared to today's potential timberline, following an assumed increase in mean summer temperature of $1.0^{\circ} \mathrm{C}$. According to the alpine model, suitable chamois habitat was found only above the alpine timberline, i.e., in the Alps. Late Mesolithic/Neolithic settlements $(N=47)$ are indicated for presence (solid circles) or absence (open circles) of fossil chamois bones.

covered were arcsine transformed, and all variables were standardized before analyses. Forward stepwise logistic regression models were applied separately for the Alpine region and the combined Jura/Plateau region, resulting in two empirical habitat models (Table 2). Probability values for stepwise entry and removal were set to 0.05 .

2. Defining Neolithic landscape parameters.-All landscape parameters associated with chamois presence (Table 2) were spatially reconstructed for the Neolithic environment. We assumed altitude, relief, topography, and glaciers to be the same as they are today, which seems justified by the geologically short time span and the largely similar climatic conditions (Stöckli et al. 1995). Forest cover was modeled as described above, assuming a temperature increase of $1.0^{\circ} \mathrm{C}$ (Brzeziecki et al. 1995). Accordingly, we assumed that zonal forests covered all terrestrial areas below the alpine timberline.

3. Building the forest model.-We applied logistic regression models to separately reconstruct Neolithic chamois forest distribution for the Swiss Alpine region and the Jura/Plateau region, utilizing the parameter es- timates from step 1 and the landscape parameters from step 2, and using grid cells of $1 \mathrm{~km}^{2}$. The resulting values were then grouped into four classes of habitat suitability: $0-25 \%, 25-50 \%, 50-75 \%$, and $75-100 \%$ (Fig. 3).

\section{Model validation}

We validated these opposing models of Neolithic chamois distribution with archaeozoological data. First, we calculated the shortest planimetric distances between any archaeological find locality and (a) the nearest alpine timberline according to the alpine model, and (b) the center of the nearest grid cell with minimal habitat suitability according to the forest model. Several independent variables resulted for each habitat model: for the alpine model, the variables D_Tline ${ }^{\left(-0.5^{\circ}\right)}$, D_ Tline ${ }^{\left(+0.0^{\circ}\right)}$, D_Tline ${ }^{\left(+0.5^{\circ}\right)}, D_{-}$Tline ${ }^{\left(+1.0^{\circ}\right)}$, and D_ Tline ${ }^{\left(+1.5^{\circ}\right)}$; and, for the forest model, D_25, D_50, and D_75. For example, D_Tline ${ }^{\left(-0.5^{\circ}\right)}$ depicts the nearest distance to the Neolithic alpine timberline, given a temperature decrease of $0.5^{\circ} \mathrm{C}$ as compared to today's tem- 
TABLE 1. Summary of the environmental variables used to analyze extant chamois distribution.

\begin{tabular}{|c|c|}
\hline Parameter & Description \\
\hline Altitude & $\begin{array}{l}\text { Classified into } 400-\mathrm{m} \text { categories, except the initial category which included } 0-600 \mathrm{~m} \text { a.s.1. Data } \\
\text { origin: DHM25† }\end{array}$ \\
\hline Slope & $\begin{array}{l}\text { Classified into } 10^{\circ} \text { categories, except the two first categories which included } 0-5^{\circ} \text { and } 5-10^{\circ} \text {. Data } \\
\text { origin: DHM } 25 \dagger\end{array}$ \\
\hline Exposition & $\begin{array}{l}\text { Classified into eight } 45^{\circ} \text { categories, starting with a value of } 281.25^{\circ} \text { plus a category of no exposi- } \\
\text { tion. Data origin: DHM } 25^{\dagger}\end{array}$ \\
\hline Fore & Area covered by forests. Data origin: Vektor $25 \ddagger$ \\
\hline Forest area & $\begin{array}{l}\text { Summarizes forest cover for every cell from its neighboring cells, after applying a cut value of } \\
0.5 \text { : values } \geq 50 \%=1 \text { and } \leq 50 \%=0 \text {. Values from cells sharing a common side were multi- } \\
\text { plied by } 3 \text {, cells that meet over a corner by } 1 \text {. }\end{array}$ \\
\hline Glacier & Area covered by glaciers or ethernal snow. Data origin: Vektor $25 \ddagger$ \\
\hline Relief & $\begin{array}{l}\text { Indicates the maximum difference in altitude for each square kilometer between } 16 \text { points regular- } \\
\text { ly spaced within grid cells } 250 \mathrm{~m} \text { apart. Data origin: DHM50 } \dagger\end{array}$ \\
\hline
\end{tabular}

Note: Parameters entered the model as the percentage of planimetric area covered per category and square kilometer, with the exception of relief and forest area, which are described herein.

$\dagger$ Digital altitude model with a grid size of $25 \mathrm{~m}$ (DHM25) or $50 \mathrm{~m}$ (DHM50).

$\ddagger$ Digital map of Switzerland 1:25 000 (vector data).

perature, whereas D_25 depicts the distance to the nearest grid cell with habitat suitability higher than $25 \%$.

As a starting point, we concentrate on D_Tline ${ }^{\left(+1.0^{\circ}\right)}$ and D_50 to model the binary outcome variable (i.e., chamois occurrence). Due to a lack of co-linearity (Spearman correlation coefficient; $N=47, R=0.016$, $P=0.287$ ), both variables were entered simultaneously in an all-effects Generalized Linear Model (GLM) with logit link function (dichotomous logistic regression) and variable selection after performing log-likelihoodratio tests (type 1). We assessed model fit with reclassification tables, applying a cutoff value of 0.5 . Significance values were set to 0.05 . We used Statistica 6.0 (StatSoft 2001) and ArcInfo 7.1 (ESRI 1998).

\section{RESULTS}

Hypothesized chamois habitat, when calculated with the alpine model, is generally farther away from Neolithic settlements than when calculated with the forest model. For alpine habitat, median distance estimates vary from 41.2 to $49.1 \mathrm{~km}$; for forest habitat, they vary from 2.9 to $4.6 \mathrm{~km}$. When we stratify the Neolithic sites according to the occurrence of fossil chamois bones (presence/absence), they differ only in their median distances to the nearest forest habitat (i.e., variables D_25 to D_75), but not in their median distances to the nearest alpine habitat (i.e., variables D_Tline ${ }^{\left(-0.5^{\circ}\right)}$ to D_Tline ${ }^{\left(+1.5^{\circ}\right)}$ ) (Table 3).

TABLE 2. Results of the analysis of female chamois distribution within two regions of the canton of Bern: the alpine region and the Jura/plateau region.

\begin{tabular}{|c|c|c|c|c|c|c|}
\hline \multirow[b]{2}{*}{ Parameter } & \multicolumn{3}{|c|}{ Alpine region $\dagger$} & \multicolumn{3}{|c|}{ Jura/Plateau region } \\
\hline & $\beta$ & SE & Wald $\chi^{2}$ & $\beta$ & SE & Wald $\chi^{2}$ \\
\hline Intercept & 0.066 & 0.146 & 0.200 & -4.174 & 0.236 & 312.26 \\
\hline \multicolumn{7}{|l|}{ Slope } \\
\hline $\begin{array}{l}0-5^{\circ} \\
30-40^{\circ} \\
>40^{\circ}\end{array}$ & $\begin{array}{r}-2.725 \\
4.462\end{array}$ & $\begin{array}{l}0.339 \\
0.550\end{array}$ & $\begin{array}{l}64.67 \\
65.86\end{array}$ & 37.535 & 4.756 & 62.29 \\
\hline \multicolumn{7}{|l|}{ Altitude } \\
\hline $\begin{array}{l}2100-2400 \mathrm{~m} \\
1800-2100 \mathrm{~m} \\
1500-1800 \mathrm{~m}\end{array}$ & $\begin{array}{l}3.901 \\
2.958 \\
1.478\end{array}$ & $\begin{array}{l}0.548 \\
0.441 \\
0.272\end{array}$ & $\begin{array}{l}50.67 \\
44.93 \\
29.54\end{array}$ & & & \\
\hline $1200-1500 \mathrm{~m}$ & & & & 1.869 & 0.385 & 23.57 \\
\hline $\begin{array}{l}600-900 \mathrm{~m} \\
0-600 \mathrm{~m}\end{array}$ & -1.238 & 0.249 & 24.69 & -2.374 & 0.473 & 25.22 \\
\hline Glaciers & -2.318 & 0.274 & 71.45 & & & \\
\hline Forest area & 0.150 & 0.021 & 52.10 & 0.090 & 0.020 & 19.88 \\
\hline Relief & & & & 0.002 & 0.0003 & 63.16 \\
\hline
\end{tabular}

Notes: Only variables that were significantly retained in at least one of the models are shown (forward stepwise logistic regression). The corresponding Somer's $D$ values are 0.76 for the alpine region and 0.85 for the Jura/plateau region.

$\dagger$ Area $=2767 \mathrm{~km}^{2}$, chamois presence $=2160 \mathrm{~km}^{2}$, chamois absence $=607 \mathrm{~km}^{2}$.

\# Area $=2766 \mathrm{~km}^{2}$, chamois presence $=354 \mathrm{~km}^{2}$, chamois absence $=2412 \mathrm{~km}^{2}$. 


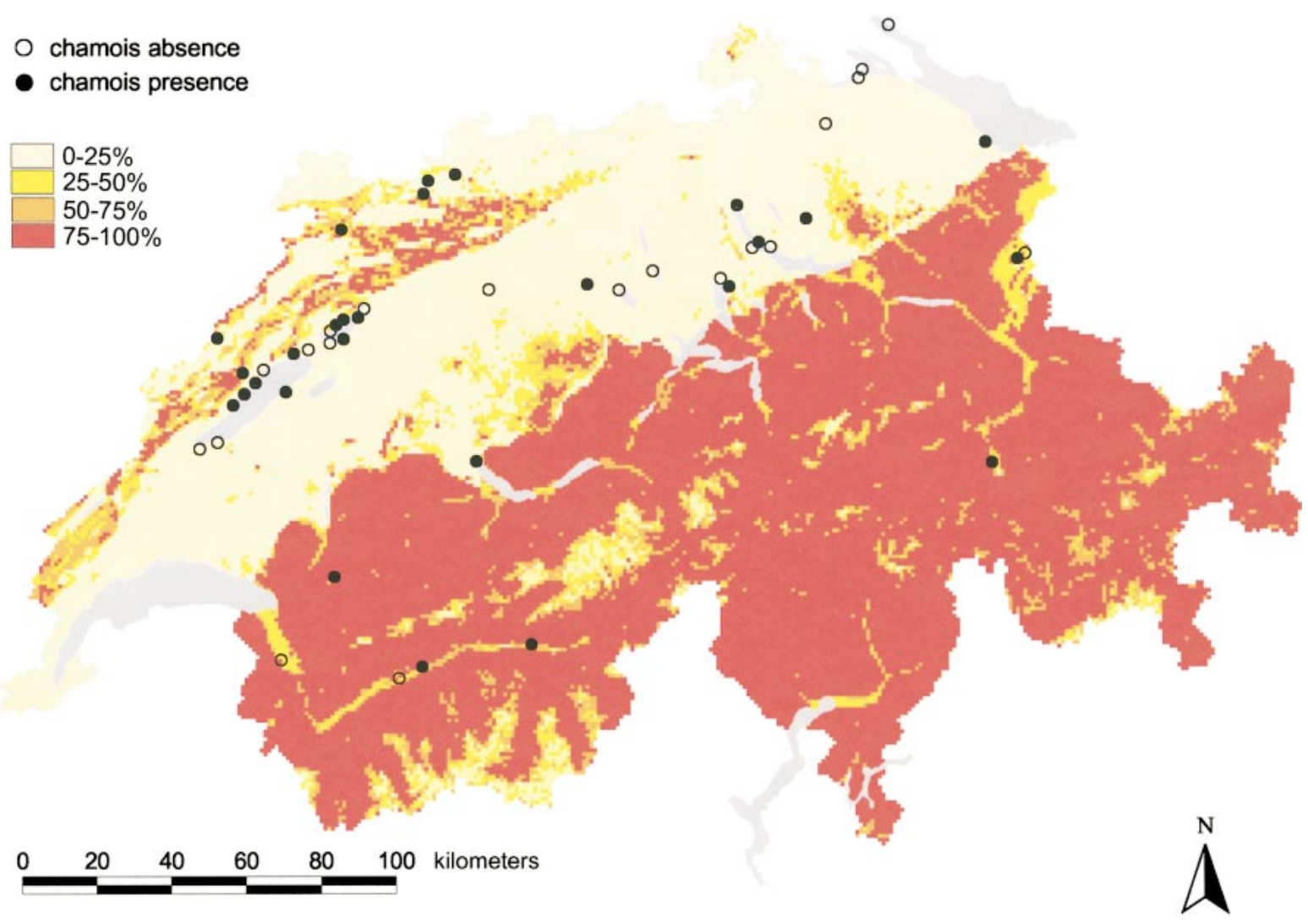

FIG. 3. Model of Late Mesolithic/Neolithic chamois distribution in Switzerland according to the forest model. One of four habitat suitability classes $(0-25 \%, 25-50 \%, 50-75 \%$, or $75-100 \%)$ is attributed to each grid cell $\left(\mathrm{km}^{2}\right)$. Chamois habitat was found both above and below the alpine timberline: in the Alps, in the pre-Alps, and in the disjunct Jura Mountains in the northwest, but not on the Central Plateau. Late Mesolithic/Neolithic settlements $(N=47)$ are shown and identified for presence (solid circles) or absence (open circles) of fossil chamois bones.

TABLE 3. Description of nearest distances $(\mathrm{km})$ between Late Mesolithic/Neolithic settlements and either chamois forest habitat (variables D_25 to D_75) or alpine habitat (variables D_Tline ${ }^{\left(-0.5^{\circ}\right)}$ to D_Tline ${ }^{\left(+1.5^{\circ}\right)}$ ), with settlements stratified by occurrence of fossil chamois bones.

\begin{tabular}{llccccc}
\hline \hline Variable & $\begin{array}{c}\text { Chamois } \\
\text { occurrence }\end{array}$ & Median & $\begin{array}{c}\text { 10th } \\
\text { percentile }\end{array}$ & $\begin{array}{c}\text { 90th } \\
\text { percentile }\end{array}$ & \multicolumn{1}{c}{$Z$} & $P$ \\
\hline D_25 & presence & 1.65 & 0.25 & 6.52 & -2.31 & 0.021 \\
& absence & 3.98 & 0.41 & 24.13 & & \\
D_50 & presence & 2.79 & 0.35 & 8.63 & -2.18 & 0.029 \\
& absence & 5.30 & 0.47 & 32.40 & & \\
D_75 & presence & 3.54 & 0.65 & 12.31 & -2.64 & 0.008 \\
& absence & 7.76 & 1.11 & 32.40 & & \\
D_Tline ${ }^{\left(-0.5^{\circ}\right)}$ & presence & 41.97 & 3.24 & 70.90 & 0.15 & 0.880 \\
D_Tline ${ }^{\left(+0.0^{\circ}\right)}$ & absence & 39.59 & 7.38 & 53.31 & & \\
& presence & 43.43 & 3.47 & 72.75 & 0.13 & 0.897 \\
D_Tline ${ }^{\left(+0.5^{\circ}\right)}$ & absence & 43.76 & 7.54 & 53.38 & & \\
D_Tline & presence & 43.69 & 3.69 & 74.29 & 0.02 & 0.983 \\
& absence & 45.14 & 7.63 & 53.45 & & \\
D_Tline & presence & 48.37 & 5.15 & 81.33 & 0.15 & 0.880 \\
& absence & 47.82 & 8.57 & 59.63 & & \\
& presence & 49.04 & 5.60 & 81.65 & 0.28 & 0.780 \\
\hline
\end{tabular}

Note: Mann-Whitney $U$ tests (two-tailed) were used to test for differences. 
TABLE 4. Results of a logistic regression model that simultaneously includes (1) the distance to chamois forest habitat (D_50) and (2) the distance to chamois alpine habitat $\left(D_{-}\right.$Tline ${ }^{\left(+1.0^{\circ}\right)}$ ) to model chamois bone occurrence within the fossil record of Late Mesolithic/Neolithic settlements $(N=47)$.

a) Parameter estimates with confidence limits

\begin{tabular}{lrccrrr} 
& & & & & \multicolumn{2}{c}{$95 \%$ CL } \\
\cline { 5 - 7 } Variables & \multicolumn{1}{c}{$\beta$} & SE & Wald $\chi^{2}$ & Wald $P$ & Lower & Upper \\
\hline Intercept & 0.647 & 0.718 & 0.812 & 0.367 & -0.760 & 2.055 \\
D_50 & -0.163 & 0.072 & 5.118 & 0.023 & -0.305 & -0.021 \\
D_Tline $^{\left(+1.0^{\circ}\right)}$ & 0.014 & 0.015 & 0.809 & 0.368 & -0.016 & 0.043
\end{tabular}

b) Associated tests of effect size

\begin{tabular}{lcccc}
\multicolumn{1}{c}{ Effect } & $\mathrm{df}$ & Log-likelihood & $\chi^{2 \dagger}$ & $P$ \\
\hline Intercept & 1 & -32.055 & & \\
D_50 & 1 & -27.193 & 9.724 & 0.0018 \\
D_Tline ${ }^{\left(+1.0^{\circ}\right.}$ & 1 & -26.780 & 0.824 & 0.364 \\
\hline
\end{tabular}

$\dagger$ Log-likelihood ratio test type 1 .

When we simultaneously enter the two independent variables D_50 and D_Tline ${ }^{\left(+1.0^{\circ}\right)}$ in a logistic regression model, only D_50 significantly improves the model fit (Table 4). This result is consistent for all other possible combinations of distances to alpine habitat and forest habitat (results not shown). Therefore, only the distance from archaeological settlements to chamois forest habitat helps to explain the occurrence of chamois bones in the fossil record.

For parameter estimation, we built three single-variable models, each containing either D_25, D_50, or D_75 as the independent variable (Table 5). In all three models, the probability of chamois bone occurrence $P(x)$ diminishes in a sigmoidal manner with increasing distance between settlement and the nearest chamois forest habitat (Fig. 4). The overall reclassification rates for these models are similar, varying between $66 \%$ and $68 \%$, while prediction of chamois bone presence is generally superior to prediction of its absence (Table 6).

For graphical comparison (and despite their nonsignificance in the all-effects models, see above), we present the functions of three logistic regression models, using the distances to alpine habitat as independent variables, i.e., D_Tline ${ }^{\left(-0.5^{\circ}\right)}, \mathrm{D}_{-} \mathrm{Tline}^{\left(+1.0^{\circ}\right)}$, and $\mathrm{D}_{-}$ Tline $^{\left(+1.5^{\circ}\right)}$ (Fig. 5). Accordingly, the probability of chamois bone occurrence $P(x)$ is not related to settlement proximity to alpine habitat. All three functions appear similar, which indicates that this result is in- sensitive to the assumed variation in altitude (about $300 \mathrm{~m}$ ) of the alpine timberline.

\section{DISCUSSION}

In our investigation of native distribution of alpine chamois in Switzerland, we utilized an interdisciplinary approach, combining ecological models with archaeozoological data. Our results show that during pristine Holocene conditions, the spatial pattern of chamois bone occurrence can be explained with a chamois habitat model that depends mainly on topography (e.g., habitat steepness) and, to a much lesser extent, vegetation (e.g., forests vs. pastures). Native chamois range included steep, entirely forested regions, even outside the Alps. Chamois disappeared from such areas only in post-Neolithic times. Therefore, their range expansion in the late 19th and 20th centuries constitutes a repatriation of native habitat.

Chamois habitat appears to include both alpine grassland and steep forests, thus indicating no habitat restrictions on chamois distribution. This conclusion, however, challenges the prevailing concept of chamois biology (Schröder and Georgii 1988) deduced from studies of chamois habitat use (e.g., Elsner-Schack 1985, Shank 1985). It provides support instead for alternative theories that suggest a disposition of chamois for forested habitat (Couturier 1938, Heptner et al. 1989). Even though our study does not consider pos-

TABLE 5. Parameter estimates and confidence limits for three logistic regression models that relate chamois bone occurrence within the fossil record of Late Mesolithic/Neolithic settlements $(N=47)$ solely to settlement distance to chamois forest habitat of increasing suitability (i.e., variables D_25, D_50, or D_75).

\begin{tabular}{|c|c|c|c|c|c|c|c|}
\hline \multirow[b]{2}{*}{ Model } & \multirow[b]{2}{*}{ Variables } & \multirow[b]{2}{*}{$\beta$} & \multirow[b]{2}{*}{ SE } & \multicolumn{2}{|c|}{ Wald } & \multicolumn{2}{|c|}{$95 \% \mathrm{CL}$} \\
\hline & & & & $x^{2}$ & $P$ & Lower & Upper \\
\hline \multirow{2}{*}{ (1) } & intercept & 1.157 & 0.484 & 5.718 & 0.017 & 0.209 & 0.105 \\
\hline & D_25 & -0.209 & 0.104 & 4.077 & 0.043 & -0.412 & -0.006 \\
\hline \multirow[t]{2}{*}{ (2) } & intercept & 1.172 & 0.459 & 6.517 & 0.010 & 0.272 & 2.072 \\
\hline & D_50 & -0.155 & 0.070 & 4.860 & 0.027 & -0.292 & -0.017 \\
\hline \multirow[t]{2}{*}{ (3) } & intercept & 1.243 & 0.480 & 6.721 & 0.009 & 0.303 & 2.183 \\
\hline & D_75 & -0.133 & 0.057 & 5.493 & 0.019 & -0.245 & -0.022 \\
\hline
\end{tabular}




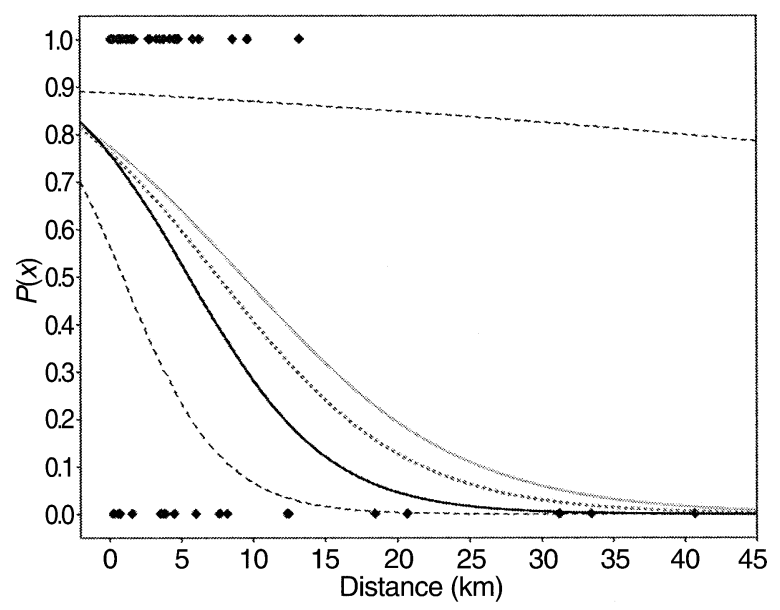

FIG. 4. Probability functions of chamois bone occurrence within the fossil record of Late Mesolithic/Neolithic settlements $P(x)$, depending on settlement distance from forest habitat. The fitted functions appear as a gray line for D_25, a dotted line for D_50, and a black line for D_75; dashed lines represent the $95 \%$ confidence interval for the function D_50. Late Mesolithic/Neolithic settlements (solid diamonds) are indicated for presence (shown at 1.0) or absence (shown at $0.0)$ of fossil chamois bones.

sible fitness consequences associated with forest habitat, it may pinpoint the difficulties of determining the importance of different habitat types from descriptive studies of their use (Garshelis 2000). On the other hand, our results may reveal the phylogenetic relationship of chamois with other, mainly forest-dwelling Rupicapridae species (Schaller 1977).

Our results cannot be explained unambiguously by either the spatial description of archaeozoological data (which may explain presence data, but not absence data) or the extrapolation of speculative habitat models into past times. Instead, logistic regression combines both of these aspects and, at the same time, offers the advantage of calculating the likelihood of fossil presence and absence. In this respect, however, our expectations are not entirely met. We observe strong dichotomy of fit, with our model allowing us to predict real presence much better than real absence ( $85 \%$ correct vs. $45 \%$ correct). In other words, we "erroneously" predict chamois presence for many sites where the species is obviously missing. Unfortunately, this divergence may be due to the very nature of the archaeozoological record: for many reasons, the record of a species may simply be missing, despite historical presence of that species and its consumption by humans (Reitz and Wing 1999). Factors that may account for this gap are the contingencies of human hunting success, the haphazard nature of larder processing, and preservation conditions, or pure chance due to small sample size (O’Connell 1995). To minimize such flaws, we emphasize the importance of carefully checking the suitability of archaeological material.
TABLE 6. Reclassification tables for the three logistic regression models from Table 5, which include D_25, D_50, or D_75 as the independent variable to model chamois bone occurrence within the fossil record of Late Mesolithic/Neolithic settlements $(N=47)$.

\begin{tabular}{llccc}
\hline \hline \multirow{2}{*}{ Model } & & \multicolumn{2}{c}{ Predicted } & Correct \\
\cline { 3 - 4 } & Observed & Absence & Presence & $(\%)$ \\
\hline (1) D_25 & absence & 8 & 12 & 40 \\
& presence & 4 & 23 & 85 \\
& overall & & & 66 \\
(2) D_50 & absence & 9 & 11 & 45 \\
& presence & 4 & 23 & 85 \\
& overall & & & 68 \\
(3) D_75 & absence & 9 & 11 & 45 \\
& presence & 4 & 23 & 85 \\
& overall & & & 68 \\
\hline
\end{tabular}

Note: Cutoff value was 0.5 .

In order to evaluate the possibility that chamois forest distribution was restricted to core habitat (e.g., the steepest parts), we calculated three different models that include distance estimates to forest habitat of increasing suitability (D_25, D_50, and D_75). These models are all rather similar, and none appears superior from a statistical point of view. Nonetheless, their functions span a considerable range for deducing possible relationships. While the probability of chamois bone presence in settlements at $0 \mathrm{~km}$ distance from chamois habitat is about $77 \%$ for all three models, the probability of such occurrence is $50 \%$ at $5.5,7.5$, and 9.5 $\mathrm{km}$ distance, and $10 \%$ at 16,22 , and $26 \mathrm{~km}$ distance. The model D_25, which assumes the widest distribution of forest chamois, always provides the most proximate distance estimates. Yet sites with a false absence

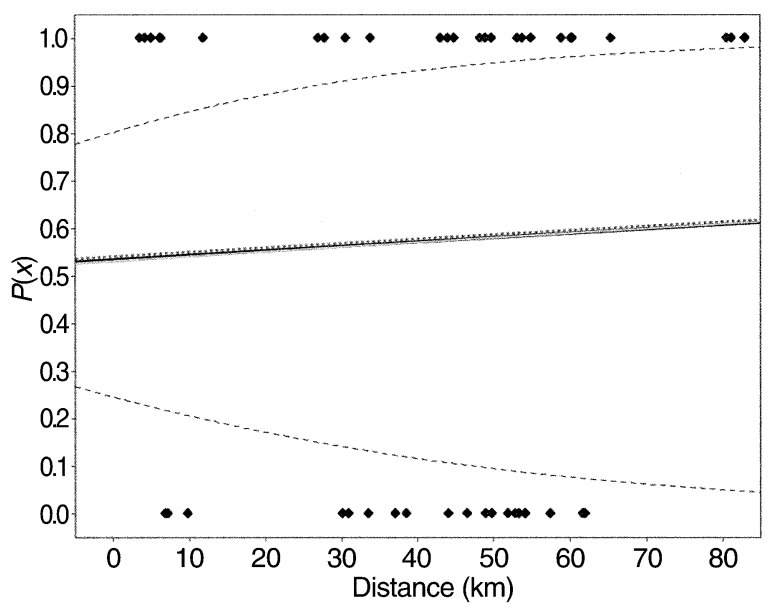

FIG. 5. Probability functions of chamois bone occurrence within the fossil record of Late Mesolithic/Neolithic settlements $P(x)$, depending on settlement distance from alpine habitat. The fitted functions appear as juxtaposed lines, gray for D_Tline ${ }^{\left(-0.5^{\circ}\right)}$, dotted for D_Tline ${ }^{\left(+1.0^{\circ}\right)}$, and black for D Tline $^{\left(+1.5^{\circ}\right)}$; dashed lines represent the $95 \%$ confidence interval for the function D_Tline ${ }^{\left(+1.0^{\circ}\right)}$. Late Mesolithic/Neolithic settlements (solid diamonds) are indicated for presence (shown at 1.0) or absence (shown at 0.0 ) of fossil chamois bones. 
of chamois bones biased these functions. Actual presence sites may therefore provide more meaningful estimates of capture probabilities. According to our results, $90 \%$ of these sites are situated closer than 6.5 , 8.6 , or $12.5 \mathrm{~km}$ from chamois forest habitat of increasing suitability.

However, do such distance estimates of capture probabilities reflect the spatial behavior of Neolithic hunters? To answer this question, we drew an analogy with the roaming patterns of extant human subsistence hunters on foot within pristine forest environments. Wilkie et al. (1997) observed that the catchment distance was mainly constrained to within $15 \mathrm{~km}$ around settlements, while Fa and Garcia-Yuste (2001) found that the average radius of circular catchment areas was $4.5 \mathrm{~km}$ and varied from 1.5 to $10 \mathrm{~km}$, depending on the number of hunters using those areas. Our models thus suggest a broadly comparable spatial behavior in Neolithic times. Interestingly, the model that assumes the widest chamois forest distribution (i.e., D_25) seems to fit best. On the other hand, the interpretation of functions provided by the alpine model does not agree at all with such empirically observed human hunting behavior and catchment distances, and neither does the $60 \%$ chamois catchment probability within $80 \mathrm{~km}$ distance of alpine habitat nor the median distance from archaeological presence sites to the nearest alpine habitat (which varies from 41 to $49 \mathrm{~km}$, depending on the assumed height of the alpine timberline).

Because our models do not account for the longdistance behavior of chamois, it could be suggested that recovered bones might stem from single animals migrating or dispersing from alpine habitat rather than from humans hunting them in the alpine regions. However, assuming identical chamois behavior then and now, we do not believe that such migrations or dispersals could generally account for the observed pattern of chamois bone depositions. Today, European chamois are philopatric, and their home ranges are most often much smaller than 500 ha (Jullien et al. 1997). Moreover, while performing their frequently observed, seasonal home-range shifts in altitude, they cover only short distances; to date, no long-distance migration has been observed (Hamr 1985, Pépin et al. 1991). Though dispersal of chamois occurs rather frequently, dispersing individuals mainly follow steep habitat features; long distance dispersal over unsuitable habitat is rare (Loison et al. 1999). Therefore, such a scenario cannot explain the observed spatial gap of chamois bone recoveries on the Central Plateau.

Our results suggest a much wider distribution of chamois in the Holocene pristine forest environment than was previously known. However, it has been documented that chamois roamed even wider during the Late Pleistocene (Couturier 1938), but in Central Europe they disappeared from most of their Pleistocene range until the Early Holocene, a fate shared by other mountain ungulates, such as alpine ibex (Capra ibex)
(Chaix and Desse 1994). At this same time, many large mammal species faced extinction (Stuart 1991). What was responsible for these drastic changes at the onset of the Holocene? While environmental change may account for many of these changes, overexploitation of large mammals is an equally plausible causative factor (Alroy 2001). Most likely, both factors acted synergistically (Bradshaw 1999). The case of alpine chamois is particularly interesting, for despite drastic environmental changes in the Early Holocene, they managed to survive for thousands of years in the Swiss Jura Mountains (in areas covered entirely by forests). Hence, environmental change alone cannot account for the withdrawal of alpine chamois from this mountain range, and we assume instead that humans displaced them in post-Neolithic times. Overharvesting seems to be the likely reason for this: Given the moderate fecundity rates of female chamois (Houssin et al. 1993) and their high adult survival rates (Loison and Gaillard 1999), chamois population growth is especially sensitive to additive adult female mortality (Gaillard et al. 2000). Small and disjunct populations at the edge of the distribution are even more susceptible to negative stochastic and demographic processes, and populations living in forests may suffer additionally from enhanced predation rates by forest carnivores (Seip 1992). Unfortunately, historical records for the regional extirpation of Swiss chamois are scant, and it is therefore uncertain exactly when chamois eradication in the Jura Mountains occurred. Interestingly, Couturier (1938) noted erratic killings of single chamois in these mountains in the early years of the 20th century, long before the first animals were released there in the 1950s (Salzmann 1977). If these erratically killed individuals were the last survivors of ancient populations, final extirpation of Swiss chamois would have taken place only recently.

\section{Management Recommendations}

Our study has implications for the future management of chamois in Switzerland. First, we will discuss spatial management of chamois on a landscape scale; and second, we will consider the local management of populations with regard to their habitat.

At the landscape scale, we advocate maximizing chamois distribution within as much of the native chamois range as possible, while also maintaining connectivity between subpopulations. Chamois populations should be kept at a level where natural selection overrides genetic drift as the main evolutionary force (Frankham et al. 2002). To increase adaptive diversity of the species (Sherwin and Moritz 2000), local and peripheral subpopulations may become important as soon as they are forced to adapt to local habitat conditions (Hoffmann and Blows 1994, Lesica and Allendorf 1996). The conservation of peripheral chamois forest populations may therefore help to increase the evolutionary potential of the species. 
In addition, a wide distribution of chamois and their occupation of diverse habitat may be justified by their pivotal ecological role (Harris et al. 2001). The chamois is unique in its ability to adapt to very steep habitat, endure severe winters with snow-covered ground, and feed on a variety of vegetation types. Chamois, therefore, cannot be substituted entirely by other native ungulates, such as roe deer, red deer, or ibex. For example, as prey for large carnivores, chamois may be playing a vital ecological role. Chamois living in forests contribute considerably to the diet of lynx (Jobin et al. 2000), and initiatives to restore large carnivores in Switzerland (Breitenmoser 1998) depend on bottomup factors and may thus profit from an increase in the carnivores' prey base (Fuller and Sievert 2001).

On a proximate level, the spatial management of chamois requires maps of both the native habitat and the present potential habitat. Scaling down from this overall view to regional management units will ensure that regional actions are meaningful in a broader context (Harris et al. 2001). For Switzerland, the hypothetical map of native chamois distribution developed within the context of this study coincides sufficiently with actual chamois distribution (Krämer 1995). Chamois landscape management must therefore concentrate on preventing intentional or nonintentional loss of local subpopulations, and on improving or maintaining faunal connectivity corridors (Bennet 2003). Given some almost permanent barriers to chamois dispersal in Switzerland (e.g., the Central Plateau), the inclusion of population genetic considerations should be evaluated for use in the future management of small and disjunct populations, such as Jura chamois (Crandall et al. 2000).

Nevertheless, the goal of assuring a wide distribution of chamois should avoid subsequent overabundance. Chamois populations should be kept in balance with their habitat to prevent both habitat deterioration and damage to vegetation (Ammer 1996). Nevertheless, two peculiarities of chamois behavior provide a challenge to oversimplified damage prevention: first, dependency of chamois on habitat steepness (Pérez-Barberia and Nores 1994); and second, philopatric group living by females (Loison et al. 1999). Both of these traits are likely to have evolved as antipredatory strategies, as they did in other mountain ungulates (Shackelton and Bunnell 1989). Thus, chamois will always concentrate in areas of secure habitat, most pronouncedly during the lambing and early nursing periods (Berger 1991) but also during winter. If such habitat is scarce and heterogeneously distributed, local concentrations of animals will occur, resulting in enhanced levels of impact. To prevent such "hot spots" of damage, most, if not all, chamois living in the area would have to be eradicated. Because such locally restricted areas are of crucial importance to the regional persistence of chamois, we propose delimiting them as "chamois core areas." In these areas, a larger impact on vegetation should be tolerated.

In this respect, chamois may benefit from recent federal forest legislation in Switzerland (BUWAL 2002). This law states that forest areas important for the regional persistence of native ungulate populations (referred to as "ungulate priority areas") must be regionally delimited. To prevent overbrowsing within such zones, culling is not the only authorized solution; other, more specialized management actions (such as minimizing the effects of recreational disturbances on chamois, or habitat improvements) may be funded. Yet, in the remaining forest area (which must cover at least $75 \%$ of the entire forest area), natural rejuvenation of all native forest tree species must be ensured without using any technical anti-browsing measures. Thus, to this extent, hunting must regulate wild ungulate populations on at least three-quarters of the forest area of Switzerland. The consistent application of this concept will thus benefit not only forests but also chamois.

\section{General Applications}

Our study demonstrates that the ecological plasticity of species might be underestimated. Native distribution might have been larger, and habitat selection more diverse, than previously assumed, thus evoking suggestions for repatriating native but now vacant areas. In addition to focusing on restoration ecology (Harris et al. 2001), the results may also be of interest to (paleo)biogeographers (Lieberman 2003) interested in the recent past, providing them with temporally and spatially distinct maps of the landscape distribution of target species. Investigators may thus be able to track Late Pleistocene and Holocene extinction patterns in more detail.

One drawback to this approach, however, may be its requirement of spatially explicit, past environmental data. Nonetheless, given the increasing availability of GIS databases and modeling techniques, as well as improvements in paleoclimatical and paleobiological knowledge, future applications are highly likely. A further objection may be based on the occurrence of false absence data in the archaeological record. To avoid this possibly serious problem, ecological niche factor analysis (ENFA; Hirzel et al. 2002) may provide the relevant and appropriate approach. ENFA is a newly developed technique for modeling distribution patterns, and it makes inferences regarding habitat suitability from presence sites only. Therefore, once the problem of archaeological sites not automatically corresponding to kill sites is solved, it may become an important tool for interpreting the fossil record. This approach could be of interest to not only researchers in the biological disciplines but also archaeologists investigating the foraging economies of past peoples; due to such spatially explicit maps of past animal distribution, they may be able to more closely relate human hunting behavior to environmental conditions. 


\section{ACKNOWLEDGMENTS}

The study was supported by Grant 310.94 .159 from the Swiss Agency for the Environment, Forests, and Landscape (SAEFL) to M. Baumann. The authors acknowledge collaboration and GIS support from Werner Suter, Felix Kienast, and Roman Eyholzer. The game wardens of the canton of Berne provided chamois distribution maps. Marcel Veszeli compiled the archaeozoological database. Stefanie Jacomet and Brigitta Amman provided valuable hints about vegetation history. English in the text was improved by John T. Borst. The manuscript profited from Kathreen Ruckstuhl and indepth comments of two anonymous referees and an Associated Editor of Ecological Applications. The Swiss Federal Institute of Topography (SWISSTOPO) authorized the application of GIS data.

\section{Literature Cited}

Alroy, J. 2001. A multispecies overkill simulation of the end-Pleistocene Mega faunal mass extinction. Science 292:1893-1896.

Amman, B. 1988. Palynological evidence of prehistoric anthropogenic forest changes on the Swiss plateau. Pages 289-301 in H. Birks, H. J. Birks, P. Kaland, and D. Moe, editors. The cultural landscape: past, present and future. Cambridge University Press, Cambridge, UK.

Ammer, C. 1996. Impact of ungulates on structure and dynamics of natural regeneration of mixed mountain forests in the Bavarian Alps. Forest Ecology and Management 88: 43-53.

Baumann, F. 1949. Die freilebenden Säugetiere der Schweiz. Huber Verlag, Bern, Switzerland.

Bennet, A. 2003. Linkages in the landscape: the role of corridors and connectivity in wildlife conservation. IUCN, Gland, Switzerland and Cambridge, UK.

Berger, J. 1990. Persistence of different-sized populations: an empirical assessment of rapid extinctions in bighorn sheep. Conservation Biology 4:91-98.

Berger, J. 1991. Pregnancy incentives, predation constraints and habitat shifts: experimental and field evidence for wild bighorn sheep. Animal Behaviour 41:61-77.

Berger, J., P. Stacey, L. Bellis, and M. Johnson. 2001. A mammalian predator-prey imbalance: grizzly bear and wolf extinction affect avian neotropical migrants. Ecological Applications 11:947-960.

Bodmer, R. 1995. Managing Amazonian wildlife: biological correlates of game choice by detribalized hunters. Ecological Applications 5:872-877.

Bradshaw, R. 1999. Spatial response of animals to climate change during the quaternary. Ecological Bulletins 47:1621.

Brassel, P., and U. Brändli, editors. 1999. Schweizerisches Landesforstinventar, Ergebnisse der Zweitaufnahme 19931995. Paul Haupt Verlag, Bern, Switzerland.

Breitenmoser, U. 1998. Large predators in the Alps: the fall and rise of man's competitors. Biological Conservation 83: 279-289.

Broseth, H., and H. Pedersen. 2000. Hunting effort and game vulnerability studies on a small scale - a new technique combining radiotelemetry, GPS and GIS. Journal of Applied Ecology 37:182-190.

Brzeziecki, B., F. Kienast, and O. Wildi. 1995. Modelling potential impacts of climate change on the spatial distribution of zonal forest communities in Switzerland. Journal of Vegetation Science 6:257-268.

Burga, C., and R. Perret. 1998. Vegetation und Klima der Schweiz seit dem jüngeren Eiszeitalter. Ott Verlag, Thun, Switzerland.

BUWAL. 2002. Eidgenössische Forstdirektion, Kreisschreiben Nr. 21 vom 31.7.2002, betreffend Wald-Wild. Bun- desamt für Umwelt, Wald und Landschaft, Bern, Switzerland.

Chaix, L., and J. Desse. 1994. Les bouquetins fossile du sudest de la France. Travaux scientifique du Parc Nationale de la Vanoise 18:17-30.

Corsi, F., J. de Leeuw, and A. Skidmore. 2000. Modeling species distribution with GIS. Pages 389-434 in L. Boitani and T. Fuller, editors. Research techniques in animal ecology: controversies and consequences. Columbia University Press, New York, New York, USA.

Corti, R. 1995. Le chamois et l'isard an France. Bulletin Mensuel Office National de la Chasse 198:14-27.

Couturier, M. 1938. Le chamois. B. Arthaud Editeur, Grenoble, France.

Crandall, K., O. Bininda-Edmonds, G. Mace, and R. Wayne. 2000. Considering evolutionary processes in conservation biology: an alternative to "evolutionary signficant units." Trends in Ecology and Evolution 15:290-295.

Ellenberg, H. 1988. Vegetative ecology of Central Europe. Fourth edition. Cambridge University Press, Cambridge, UK.

Elsner-Schack, I. 1985. What is good chamois habitat? Pages 71-75 in S. Lovari, editor. The biology and management of mountain ungulates. Croom and Helm, London, UK.

Erny-Rodmann, C., E. Gross-Klee, J. Haas, S. Jacomet, and H. Zoller. 1997. Früher "human impact" und Ackerbau im Übergangsbereich Spätmesolithikum-Frühneolithikum im schweizerischen Mittelland. Jahrbuch der Schweizerischen Gesellschaft für Ur- und Frühgeschichte 80:27-56.

ESRI. 1998. ArcInfo 7.1.1. Environmental Systems Research Institute, Inc., Redland, California, USA.

Fa, J., and J. Garcia-Yuste. 2001. Commercial bushmeat hunting in the Monte Mitra forests, Equatorial Guinea: extent and impact. Animal Biodiversity and Conservation 21: $31-52$.

Frankham, R., J. Ballou, and D. Briscoe. 2002. Conservation genetics. Cambridge University Press, Cambridge, UK.

Fuller, T., and P. Sievert. 2001. Carnivore demography and the consequences of changes in prey availability. Pages 163-178 in J. Gittleman, S. Funk, D. MacDonald, and R. Wayne, editors. Carnivore conservation. Cambridge University Press, Cambridge, UK.

Gaillard, J., M. Festa-Bianchet, N. Yoccoz, A. Loison, and C. Toïgo. 2000. Temporal variation in fitness components and population dynamics of large herbivores. Annual Review of Ecology and Systematics 31:367-393.

Garshelis, D. 2000. Delusion in habitat evaluation: measuring use, selection and importance. Pages 111-164 in L. Boitani and T. Fuller, editors. Research techniques in animal ecology: controversies and consequences. Columbia University Press, New York, New York, USA.

Giacometti, M. 1997. Alpine chamois. Pages 132-133 in D. Shackelton, editor. Wild sheep and goats and their relatives. IUCN Publication, Gland, Switzerland.

Guisan, A., and N. Zimmermann. 2000. Predictive habitat distribution models in ecology. Ecological Modelling 135: 147-186.

Gutersohn, H. 1975. Régions naturelles. Page 78 in E. Imhof, editor. Atlas de la Suisse. Office Fédéral de la Topographie, Berne, Switzerland.

Haas, J., I. Richoz, W. Tinner, and L. Wick. 1998. Synchronous Holocene climatic oscillations recorded on the Swiss Plateau and at timberline in the Alps. Holocene 8:301-309.

Hamr, J. 1985. Seasonal home-range size and utilization by female chamois in Northern Tyrol. Pages 106-116 in S. Lovari, editor. The biology and management of mountain ungulates. Croom and Helm, London, UK.

Harris, L., L. Duever, R. Meegan, T. Hoctor, J. Schortmeyer, and D. Maehr. 2001. The biotic province: minimum unit for conserving biodiversity. Pages 321-343 in D. Maehr, 
R. Noss, and J. Larkin, editors. Large mammal restoration: ecological and sociological challenges in the 21 st century. Island Press, Washington, D.C., USA.

Hawkes, K., J. O'Connell, and L. Rogers. 1997. The behavioral ecology of modern hunter-gatherers and human evolution. Trends in Ecology and Evolution 12:29-32.

Heptner, V., A. Nasimovich, and A. Bannikov. 1989. Mammals of the Soviet Union. Brill Publishers, Leiden, The Netherlands.

Herrero, J., I. Garin, A. Garcia-Serrano, and R. Garcia-Gonzales. 1996. Habitat use in a Rupicapra pyrenaica forest population. Forest Ecology and Management 88:25-29.

Higgs, E., and C. Vita-Finzi. 1972. Prehistoric economiesa territorial approach. Pages 27-36 in E. Higgs, editor. Papers on economic prehistory. Cambridge University Press, London, UK.

Hirzel, A., J. Hausser, D. Chessel, and N. Perrin. 2002. Ecological-niche factor analysis: how to compute habitat-suitability maps without absence data? Ecology 83:2027-2036.

Hochuli, S., U. Niffeler, and V. Rychner, editors. 1998. Die Schweiz vom Paläolithikum bis zum frühen Mittelalter: die Bronzezeit (SPM III). Verlag Schweizerische Gesellschaft für Ur- und Frühgeschichte, Basel, Switzerland.

Hoffmann, A., and M. Blows. 1994. Species borders: ecological and evolutionary perspectives. Trends in Ecology and Evolution 9:223-227.

Houssin, H., A. Loison, and J. M. Gaillard. 1993. Participation à la reproduction des femelles de chamois en fonction de leur âge dans une population alpine chassée. Gibier Faune Sauvage 10:39-45.

Hufthammer, A., and K. Sørensen. 1998. Late- and postglacial European roe deer. Pages 47-69 in R. Andersen, P. Duncan, and J. Linnell, editors. The European roe deer: the biology of success. Scandinavian University Press, Oslo, Norway.

Huntley, B., M. Baillie, J. Grove, C. Hammer, S. Harrison, S. Jacomet, E. Jansen, W. Karlén, N. Koç, J. Luterbacher, J. Negendank, and J. Schibler. 2002. Holocene paleoenvironmental changes in north-west Europe: climatic implications and the human dimension. Pages 259-298 in G. Wefer, W. Berger, K. Behre, and E. Jansen, editors. Climate development and history of the North Atlantic realm. Hanse, Berlin Heidelberg, Germany.

Hurlbert, S. 1984. Pseudoreplication and the design of ecological field experiments. Ecological Monographs 54:187211.

Iason, G., C. Duck, and T. H. Clutton-Brock. 1986. Grazing and reproductive success of red deer, the effect of local enrichment by gull colonies. Journal of Animal Ecology 55:507-515.

Illius, A., and I. Gordon. 1997. Scaling up from functional response to numerical response in vertebrate herbivores. Pages 397-425 in H. Olff, V. Brown, and R. Drent, editors Herbivores, between plants and predators. 38th Symposium of the British Ecological Society. Blackwell Science, London, UK

Jobin, A., P. Mollinari, and U. Breitenmoser. 2000. Prey spectrum, prey preference and consumption rates of Eurasian lynx in the Swiss Jura mountains. Acta Theriologica 45 : 243-252.

Jullien, J. M., A. Loison, and G. Pépin. 1997. Domaines vitaux des chamois des Bauges. Bulletin Mensuel de l'Office National de la Chasse 221:5-9.

Kaplan, H., and K. Hill. 1992. The evolutionary ecology of food acquisition. Pages 167-201 in E. Smith and B. Winterhalder, editors. Evolutionary ecology and human behaviour. Hawthorne, New York, New York, USA.

Knick, S., and J. Rotenberry. 2000. Ghost of habitat past, contribution of landscape change to current habitats used by shrubland birds. Ecology 81:220-227.
Krämer, A. 1995. Rupicapra rupicapra. Pages 461-466 in J. Hausser, editor. Die Säugetiere der Schweiz. Birkhäuser Verlag, Basel, Switzerland.

Lang, G. 1993. Holozäne Veränderungen der Waldgrenze in den Schweizer Alpen-Methodische Ansätze und gegenwärtiger Kenntnisstand. Pages 317-327 in C. Brombacher, S. Jacomet, and J. Haas, editors. Festschrift Zoller. Dissertationes Botanicae 196.

Lesica, P., and F. Allendorf. 1996. When are peripheral populations valuable for conservation? Conservation Biology 9:753-760.

leTensorer, J. M., and U. Niffeler, editors. 1993. Die Schweiz vom Paläolithikum bis zum frühen Mitelalter: Paläolithikum und Mesolithikum (SPM I). Verlag Schweizerische Gesellschaft für Ur- und Frühgeschichte, Basel, Switzerland.

Lieberman, B. 2003. Paleobiogeography: the relevance of fossils to biogeography. Annual Review of Ecology, Evolution And Systematics 34:51-69.

Loison, A., and J. M. Gaillard. 1999. Age-specific survival in five populations of ungulates: evidence of senescence. Ecology 80:2539-2554.

Loison, A., J. Jullien, and P. Menaut. 1999. Subpopulation structure and dispersal in two populations of chamois. Journal of Mammalogy 80:620-632.

Mace, G., and A. Balmford. 2000. Patterns and processes in contemporary mammalian extinction. Pages 27-52 in A. Entwistle and N. Dunstone, editors. Priorities for the conservation of mammalian diversity. Cambridge University Press, Cambridge, UK.

Mack, R., D. Simberloff, W. Lonsdale, H. Evans, M. Clout, and F. A. Bazzac. 2000. Biotic invasions: causes, epidemiology, global consequences, and control. Ecological Applications 10:689-710.

Maehr, D., R. Noss, and J. Larkin. 2001. Large mammal restoration: ecological and sociological challenges in the 21st century. Island Press, Washington, D.C., USA.

Maise, C. 1998. Archäoklimatologie: vom Einfluss nacheiszeitlicher Klimavariabilität in der Ur- und Frühgeschichte. Schweizerisches Jahrbuch für Ur- und Frühgeschichte 81:197-235.

McShea, W., H. Underwood, and J. Rappole. 1997. The science of overabundance, deer ecology and population management. Smithsonian, Washington, D.C., USA.

Metcalfe, D., and K. Balow. 1992. A model for exploring the optimal trade-off between field processing and transport. American Anthropologist 94:340-356.

Müller, F., G. Kaenel, and G. Lüscher, editors. 1999. Die Schweiz vom Paläolithikum bis zum frühen Mittelalter: Eisenzeit (SPM IV). Verlag Schweizerische Gesellschaft für Ur- und Frühgeschichte, Basel, Switzerland.

Mysterud, A., and E. Ostbye. 1999. Cover as habitat element for temperate ungulates: effects on habitat selection and demography. Wildlife Society Bulletin 27:385-394.

Niethammer, F., and F. Krapp, editors. 1986. Handbuch der Säugetiere Europas: Band 2/II, Paarhufer. Aula Verlag, Wiesbaden, Germany.

Nilsen, E., J. Linnell, and R. Andersen. 2004. Individual access to preferred habitat affects fitness components in female roe deer Capreolus capreolus. Journal of Animal Ecology 73:44-50.

Noss, R. 2001. Why restore large mammals? Pages 1-21 in D. Maehr, R. Noss, and J. Larkin, editors. Large mammal restoration: ecological and sociological challenges in the 21st century. Island Press, Washington, D.C., USA.

O'Connell, J. F. 1995. Ethnoarcheology needs a general theory of behavior. Journal of Archaeological Research 3:205255 .

Osterwalder, C., and P. Schwarz, editors. 1986. Chronologie: Archäologische Daten der Schweiz. Verlag Schweizerische 
Gesellschaft für Ur- und Frühgeschichte, Basel, Switzerland.

Patterson, B. 1999. Contingency and determinism in mammalian biogeography, the role of history. Journal of Mammalogy 80:345-360.

Pépin, D., G. Gonzales, and R. Bon. 1991. Le chamois et l'isard. La Terre et la Vie, Revue d'Ecologie, Supplément 6:111-153.

Pérez, J., J. Granados, R. Soriguer, P. Fandos, F. Marquez, and J. Crampe. 2002. Distribution, status and conservation problems of the Spanish ibex, Capra pyrenaica. Mammal Review 32:26-39.

Pérez-Barberia, F., and C. Nores. 1994. Seasonal variation in group size of Cantabrian chamois in relation to escape terrain and food. Acta Theriologica 39:295-305.

Pettorelli, N., J. Gailard, P. Duncan, J. Quellet, and G. van Laere. 2001. Spatial variations in habitat quality, local density and phenotypic quality in roe deer. Oecologica 128: 400-405.

Purvey, A. 2000. Mammalian life histories and responses of populations to exploitation. Pages 169-181 in J. D. Reynolds, G. M. Mace, K. H. Redford, and J. G. Robinson, editors. Conservation of exploited species. Cambridge University Press, Cambridge, UK.

Reitz, E., and E. Wing. 1999. Zooarchaeology. Cambridge University Press, Cambridge, UK.

Rejmànek, M., D. Richardson, M. Barbour, M. Crawley, G. Hrusa, P. Moyle, J. Randall, D. Simberloff, and M. Williamson. 2002. Biological invasions: politics and the discontinuity of ecological terminology. Bulletin of the Ecological Society of America 83:131-133.

Richard, J. 1972. Un facteur écologique nouveau dans le Jura, le chamois. Bulletin de la Société Neuchâteloise des Sciences Naturelles 95:89-95.

Salzmann, H. 1975. Die Geschichte der Gemsen im Schweizerischen Jura. Mitteilungen der Naturforschenden Gesellschaft in Bern 32:15-35.

Schaller, G. 1977. Mountain monarchs, wild sheep and goats of the Himalaya. Chicago University Press, Chicago, Illinois, USA.

Scherzinger, W. 1996. Naturschutz im Wald. Ulmer Verlag, Ulm, Germany.

Schibler, J., and S. Jacomet. 1999. Archeozoological and archeobotanical evidence of human impact on Neolithic environments in Switzerland. Pages 339-354 in N. Benecke, editor. The Holocene history of the European vertebrate fauna: modern aspects of research. VM Verlag, Rahden, Germany.

Schibler, J., S. Jacomet, H. Hüster-Plogmann, and C. Brombacher. 1997. Economic crash in the 37th and 36th centuries cal. BC in Neolithic lake shore sites in Switzerland. Anthropozoologica 25:553-570.

Schröder, W. 1971. Untersuchungen zur Ökologie des Gamswildes in einem Vorkommen der Alpen, I. Teil. Zeitschrift für Jagdwissenschaft 17:113-168.

Schröder, W. 1983. Das Gamswild, 3. Auflage. Paul Parey Verlag, Hamburg, Germany.

Schröder, W. 1985. Management of mountain ungulates. Pages 179-196 in S. Lovari, editor. The biology and management of mountain ungulates. Croom and Helm, London, UK.

Schröder, W., and I. Elsner v. d. Marlsburg. 1982. Gams und Gebirgswald: Vorschläge zur Jagd auf Gams in den Ammergauer Bergen. Forstwissenschaftliches Centralblatt 101:80-92.

Schröder, W., and B. Georgii. 1988. Ein Habitatmodell für Gams. Pages 147-160 in Gamswild-Symposium CIC, Ljubljana, Slovenia.
Seip, D. 1992. Factors limiting woodland caribou populations and their interrelationships with wolves and moose in Southeastern British Columbia. Canadian Journal of Zoology 70:1494-1503.

Shackelton, D., editor. 1997. Wild sheep and goats and their relatives. IUCN Caprinae Specialists Group. IUCN Publications, Gland, Switzerland.

Shackelton, D., and F. Bunnel. 1989. Natural factors affecting productivity of mountain ungulates: a risky existence. Pages 46-57 in B. Vetrino, editor. Reintroduction of predators in protected areas. Atti del Convegno, Torino, Italy.

Shank, C. 1985. Inter- and intra-sexual segregation of Chamois (Rupicapra rupicapra) by altitude and habitat during summer. Zeitschrift für Säugetierkunde 50:117-125.

Sherwin, W., and C. Moritz. 2000. Managing and monitoring genetic erosion. Pages 9-34 in A. Young and G. Clarke, editors. Genetics, demography and viability of fragmented populations. Cambridge University Press, Cambridge, UK.

Skogland, T. 1991. What are the effects of predators on large ungulate populations? Oikos 61:401-411.

Srikwan, S., and D. Woodruff. 2000. Genetic erosion in isolated small-mammal populations following rainforest fragmentation. Pages 149-172 in A. G. Young and G. M. Clarke, editors. Genetics, demography and viability of fragmented populations. Cambridge University Press, Cambridge, UK.

StatSoft. 2001. Statistica 6.0. StatSoft, Inc., Tulsa, Oklahoma, USA.

Stöckli, W., U. Niffeler, and E. Gross-Klee, editors. 1995. Die Schweiz vom Paläolithikum bis zum frühen Mittelalter: das Neolithikum (SPM II). Verlag Schweizerische Gesellschaft für Ur- und Frühgeschichte, Basel, Switzerland.

Stuart, A. 1991. Mammalian extinctions in the late Pleistocene of northern Eurasia and North America. Biological Review 66:453-562.

Terborgh, J., J. Estes, P. Paquet, K. Ralls, K. Boyd-Heger, B. Miller, and R. Noss. 1999. The role of top carnivores in regulating terrestrial ecosystems. Pages 39-64 in M. Soulé and J. Terborgh, editors. Continental conservation: scientific foundations of regional reserve networks. Island Press, Washington, D.C., USA.

Wiens, J. 2002. Predicting species occurrences: progress, problems and prospects. Pages 739-749 in J. Scott, P. Heglund, M. Morrison, J. Haufler, M. Raphael, W. Wall, and F. Samson, editors. Predicting species occurrences: issues of accuracy and scale. Island Press, Washington, D.C., USA.

Wilkie, D., B. Curran, R. Tshombe, and G. Morelli. 1997. Modelling the sustainability of subsistence farming and hunting in the Ituri Forest of Zaire. Conservation Biology 11:137-147.

Wilkie, D., E. Shaw, F. Rotberg, G. Morelli, and P. Auzel. 2000. Roads, development, and conservation in the Congo Basin. Conservation Biology 14:1614-1622.

Woodroffe, R. 2001. Strategies for carnivore conservation: lessons from contemporary extinctions. Pages 61-92 in J. Gittleman, S. Funk, D. MacDonald, and R. Wayne, editors. Carnivore conservation. Cambridge University Press, Cambridge, UK.

Woodroffe, R. 2003. Dispersal and conservation: a behavioral perspective on metapopulation persistence. Pages 3348 in M. Festa-Bianchet and M. Appollonio, editors. Animal behavior and wildlife conservation. Island Press, Washington, D.C., USA.

Zoller, H., and N. Haas. 1995. War Mitteleuropa ursprünglich eine halboffene Weidelandschaft oder von geschlossenen Wäldern bedeckt? Schweizerische Zeitschrift für Forstwesen 146:321-354. 